\title{
ANALISIS PENDAPATAN USAHATANI SAWI DI DESA PETLENG KECAMATAN ALOR TENGAH UTARA KABUPATEN ALOR
}

\author{
Emirensiana Latuan dan Nerci W. Mapada
}

Jurusan Agribisnis, Universitas Tribuana Kalabahi

J. Soekarno, Tang - Eng, Batunirwala, Alor 85817

Korespondensi: emirensianalatuan@gmail.com

\begin{abstract}
To get maximum income, farming must be able to increase production and reduce production costs. The research sample used the Slovin formula so that the number of samples was 50 mustard farmers. To determine the income of mustard farming and to find out whether mustard farming in Petleng Village, North Central Alor Regency is feasible or not to be developed. The data obtained were analyzed using the income formula: $=T R-T C$ and the farming feasibility formula: $R / C$ Ratio $=T R / T C$. average Total Cost $R p$. 788,200, the average income is $R p .3,740,000$ and the average farm income is $R p .2,951,800$, and the $R / C$ of mustard farming in Petleng Village is greater than 1, which is 4.74 , this means that mustard farming in Petleng Village is feasible to develop.
\end{abstract}

Key Words: income, eligibility, mustard, Petleng

\section{PENDAHULUAN}

Pertanian merupakan sector terbesar hamper dalam setiap ekonomi di Negara berkembang. Dalam pembangunan nasional sector pertanian diharapkan mampu memberikan peran yang lebih besar kepada petani dalam menentukan prioritas komoditas usaha pertanian yang menjadi usaha andalan (Damanik, 2014)

Salah satu tanaman sayur-sayuran yang banyak dibudidayakan oleh masyarakat adalah tanaman sawi (Brassica juncea). Tanaman sawi ini adalah salah satu komoditas yang memiliki nilai komersial dan prospek yang cerah dan merupakan produk pertanian yang sudah sangat dikenal dalam kehidupan sehari-hari masyarakat Indonesia. Sawi yang dikonsumsi berfungsi pula sebagai penyembuh sakit kepala. Orang-orang pun mempercayai sawi mampu bekerja sebagai bahan pembersih darah. Penderita penyakit ginjal dianjurkan untuk banyak-banyak mengkonsumsi sawi karena dapat membantu memperbaiki fungsi kerja ginjal (Misri, 2013). 
Pendapatan adalah penghasilan yang timbul dari pelaksanaan aktivitas entitas yang normal dan dikenal dengan sebutan yang berbeda, seperti penjualan, penghasilan jasa, bunga, dividen, royalti, dan sewa (Ikatan Akuntan Indonesia, 2015).

Tujuan berusahatani adalah mendapatkan keuntungan yang sebesar-besarnya dan pemilihan penggunaan faktor produksi. Keuntungan dapat ditingkatkan dengan cara meminimumkan biaya dengan mempertahankan tingkat penerimaan yang di peroleh dan meningkatkan total penerimaan dengan mempertahankan total biaya tetap. Pendapatan usahatani dapat dihitung dengan mengurangi input total (biaya) atau dengan kata lain pendapatan ialah jumlah yang tersisa setelah biaya yaitu semua nilai input untuk memproduksi yang benar-benar dibayar maupun yang hanya diperhitungkan setelah dikurangi penerimaan (Sinabariba et al., 2014).

Kecamatan Alor Tengah Utara dengan luas panen Sawi 11 Ha (Dinas Pertanian Kab. Alor, 2019). Desa Petleng dikenal sebagai salah satu daerah sentra produksi sayur sawi. Namun belum mencerminkan bahwa tingkat pendapatan yang diperoleh dari kegiatan usahataninya tinggi, hal ini terlihat dari kehidupan sosial ekonomi petani tersebut yang masih tergolong menengah pendapatan yaitu fokus pada upaya peningkatan pendapatan usahatani dengan cara mengubah orientasi hortikutura yang subsistem kearah hortikutura komersil melalui pengembangan agribisnis. Dengan demikian usahatani membudidayakan tanaman yang produktif dan laku dijual dipasaran seperti sayur sawi.

Pendapatan yang tinggi selalu diharapkan usahatani dalam menghasilkan produksi pertaniannya. Untuk mendapatkan pendapatan maksimum usahatani harus dapat meningkatkan produksi dan dapat menekan biaya produksi. Oleh karena itu usahatani harus mampu menyediakan input usahatani secara efisien. Tujuan 1). Untuk mengetahui besar pendapatan usahatani sawi di Desa Petleng Kecamatan Alor Tengah Utara Kabupaten Alor. 2). Untuk mengetahui apakah usahatani sawi di Desa Petleng Kecamatan Alor Tengah Utara layak atau tidak layak dilakukan. 


\section{METODE PENELITIAN}

\section{Penentuan Lokasi dan Waktu Penelitian}

Penelitian ini telah dilakukan di Desa Petleng kecamatan Alor Tengah Utara dari tanggal 19 Mei sampai dengan tanggal 19 Juli 2020. Pemilihan lokasi dilakukan secara sengaja (purposive) pertimbangan bahwa Desa Pailelang merupakan salah satu tempat Produksi sawi di Kabupaten Alor.

\section{Jenis dan Sumber Data}

Data primer bersumber dari petani sawi di Desa Petleng mengenai biaya-biaya produksi, jumlah produksi, harga jual dan pendapatan. Data primer yang diperoleh dari petani sawi.

\section{Metode Pengumpulan Data}

Metode pengumpulan data yang di gunakan melalui wawancara untuk bertukar informasi dan ide melalui tanya jawab, sehingga dapat dikonstruksikan makna dalam suatu topik tertentu dan pengisian kuisoner. Jumlah petani sawi di Desa Petleng100 orang. Dengan demikian yang merupakan populasi dalam penelitian ini sebanyak 100 orang petani sawi. Dari populasi sebesar 100 petani sawi maka perhitungan sampel penelitian dengan mengunakan rumus Slovin (Sudiyono, 2011), dengan mengunakan rumus Slovin tersebut serta tingkat kesalahannya 10\% dapat dihitung jumlah sampel penelitian. Maka jumlah sampel yang akan diteliti adalah sebanyak 50 orang petani sawi.

\section{Teknik Analisis Data}

\section{Analisis saluran pemasaran}

Untuk mengetahui saluran distribusi kelapa di Desa Pailelang Kecamatan Alor Barat Daya dilakukan dengan menelusuri penjualan kelapa ditingkat petani hingga konsumen. 


\section{Analisis Pendapatan sawi}

1. Analisis pendapatan. Adapun rumus pendapatan dapat di tulis sebagai berikut (Rahim et al., 2012):

a. Biaya usahatani

Untuk mengetahui biaya usahatani yang dikeluarkan oleh petani sawi di Desa Petleng maka menggunakan rumus:

$\mathrm{TC}=\mathrm{TFC}+\mathrm{TVC}$

Keterangan :

$\mathrm{TC}=$ Biaya Total

TFC $=$ Total Biaya Tetap

TVC $=$ Total Biaya Variabel

b. Penerimaan Usahatani

Penerimaan yang diperoleh petani sawi di desa Petleng maka menggunakan rumus:

$\mathrm{TR}=\mathrm{P} \times \mathrm{Q}$

Keterangan:

TR $=$ Penerimaan Total

$\mathrm{Q}=$ Jumlah produk yang dihasilkan

$\mathrm{P}=$ Harga Produk

c. Pendapatan

Pendapatan adalah besarnya penerimaan dan pengeluaran selama proses produksi diperoleh petani sawi di desa Petleng maka menggunakan rumus:

$\Pi=\mathrm{TR}-\mathrm{TC}$

Keterangan:

$\pi=$ Pendapatan $(\mathrm{Rp})$

$\mathrm{TR}=$ Total Penerimaan $/$ total revenue $(\mathrm{Rp})$

$\mathrm{TC}=$ Total biaya / total cost $(\mathrm{Rp})$

2. R/C Ratio menyatakan kelayakan suatu usaha apakah menguntungkan, impas atau suatu usaha dapat dikatakan mengalami kerugian. Secara sistematis (R/C) dapat dirumuskan sebagai berikut ((Nugroho et al., 2015) : $\mathrm{R} / \mathrm{C}$ Ratio $=\mathrm{TR} / \mathrm{TC}$ 
Keterangan $: \quad T R=$ Total Revenue

$$
\mathrm{TC}=\text { Total Cost }
$$

Kriteria berdasarkan R/C Ratio adalah :

- $\quad \mathrm{R} / \mathrm{C}$ ratio $>1$, usaha usahatani sawi layak untuk diusahakan

- $\mathrm{R} / \mathrm{C}$ ratio $=1$, maka usahatani sawi tidak untung dan tidak rugi

- $\quad \mathrm{R} / \mathrm{C}$ ratio $<1$, usaha usahatani sawi tidak layak untuk diusahakan

\section{HASIL DAN PEMBAHASAN}

\section{Analisis Pendapatan dan Analisis Kelayakan}

Usia responden terbanyak antara 40-49 tahun yaitu 17 orang atau 34\% dan jumlah usia responden terendah antara 20-29 tahun yaitu 2 Orang atau $4 \%$, petani yang melakukan usahatani sawi di Desa Petleng umumnya berjenis kelamin laki-laki yaitu sebesar $90 \%$ dengan jumlah petani sebanyak 45 orang, sedangkan perempuan hanya 5 orang dengan persentase $10 \%$. Hasil penelitian di diperoleh hasil rata-rata produksi sawi yaitu 748 ikat dengan rata-rata harga sebesar Rp. 5000/ikat.

Berdasarkan hasil penelitian terhadap pendapatan petani sawi di Desa Petleng yaitu:

\section{Analisis Pendapatan}

a. Biaya Usahatani Sawi

1). Biaya Tetap

Tabel 1. Rata-rata Biaya Tetap pada Usahatani sawi di Desa Petleng

\begin{tabular}{lc}
\hline \multicolumn{1}{c}{ Uraian } & Biaya (Rp) \\
\hline Biaya Pajak Bumi Bangunan & 24.400 \\
\hline Jumlah & $\mathbf{2 4 . 4 0 0}$ \\
\hline Sumber: Data primer diolah, 2020 &
\end{tabular}

Dari Tabel 1, menjelaskan bahwa rata -rata biaya pajak bumi bangunan yang dibayarkan petani sawi sebesar Rp. 24.400 Dalam variabel biaya tetap yang petani sawi mengeluarkan biaya yaitu biaya pajak bumi bangunan. 
2). Biaya Variabel

Tabel 2. Rata-rata Biaya Variabel pada Usahatani sawi di Desa Petleng

\begin{tabular}{lc}
\hline \multicolumn{1}{c}{ Uraian } & Biaya (Rp) \\
\hline Biaya Benih & 94.000 \\
\hline Biaya Pupuk & 148.800 \\
\hline Biaya Pestisida & 50.000 \\
\hline Biaya upah tenaga kerja & 50.000 \\
\hline Konsumsi & 50.000 \\
\hline Transportasi & 371.000 \\
\hline Jumlah & $\mathbf{7 6 3 . 8 0 0}$
\end{tabular}

Sumber: Data primer diolah, 2020

Tabel 2, menunjukkan bahwa rata -rata biaya benih Rp. 94.000, rata-rata biaya pupuk Rp. 148.800, rata-rata biaya pestisida Rp. 50.000, rata-rata biaya upah tenaga kerja Rp. 50.000, rata-rata biaya konsumsi Rp. 50.000 dan rata-rata biaya transportasi Rp. 371.000 jadi total biaya variabel $\mathrm{Rp}$ 763.800. Untuk biaya tenaga kerja menggunakan kelompok usahatani sekali kerja di bayar Rp. 50.000.

3). Total Biaya Usahatani Sawi

Tabel 3. Rata-rata Total Biaya (TC) pada Usahatani sawi di Desa Petleng

\begin{tabular}{lc}
\hline \multicolumn{1}{c}{ Uraian } & Biaya (Rp) \\
\hline Biaya Tetap & $\mathbf{2 4 . 4 0 0}$ \\
Biaya Variabel & $\mathbf{7 6 3 . 8 0 0}$ \\
\hline Total Biaya(+) & $\mathbf{7 8 8 . 2 0 0}$ \\
\hline Sumber: Data primer diolah, 2020 &
\end{tabular}

Dari Tabel 3, dapat dilihat bahwa rata-rata biaya tetap adalah Rp. 24.400 dan Rata-rata biaya variabel Rp. 763.800 jadi total biaya usahatani adalah Rp. 788.200.

b.Penerimaan Usahatani Sawi

Berdasarkan hasil penelitian di diperoleh hasil rata-rata produksi sawi yaitu 748 ikat dengan rata-rata harga sebesar Rp. 5000/ikat. Berdasarkan produksi dan harga jual persatuan produksi didapat hasil rata -rata penerimaan usahatani sawi adalah sebesar Rp. 3.740.000. Besar kecilnya penerimaan petani di daerah penelitian bervariasi tergantung dengan banyaknya produksi sawi yang dihasilkan serta harga jual yang berlaku saat itu. 
c. Pendapatan Usahatani Sawi

Tabel 4. Rata-rata Pendapatan pada Usahatani sawi di Desa Petleng

\begin{tabular}{|c|c|}
\hline Uraian & Jumlah (Rp) \\
\hline Total Penerimaan (TR) & 3.740 .000 \\
\hline Total Biaya (TC) & 788.200 \\
\hline Pendapatan (п) (-) & 2.951 .800 \\
\hline
\end{tabular}

Tabel 4, menunjukkan bahwa rata-rata pendapatan sawi di Desa Petleng adalah Rp. 2.951.800. Dari data tersebut terlihat bahwa total penerimaan lebih besar dari total biaya yang di keluarkan, hal ini berarti penerimaan petani dapat menutupi semua biaya yang dikeluarkan dalam proses produksi usahatani sawi di Desa Petleng.

\section{Analisis $R / C$ Rasio}

R/C Ratio menyatakan kelayakan suatu usahatani apakah menguntungkan, balik modal atau tidak menguntungkan (rugi). Suatu usahatani sawi dikatakan layak dan memberi manfaat apabila nilai $\mathrm{R} / \mathrm{C}$ ratio $>1$, semakin besar nilai keuntungan atas biaya maka semakin besar pula manfaat yang akan diperoleh dari usaha tersebut. Berdasarkan hasil perhitungan sistematis (R/C Rasio) maka diperoleh nilai kelayakan sebagai berikut.

$$
\begin{aligned}
\mathrm{R} / \mathrm{C} \text { Rasio } & =\mathrm{TR} / \mathrm{TC} \\
& =3.740 .000 / 788.200 \\
& =4,74
\end{aligned}
$$

Berdasarkan hasil perhitungan tersebut di atas, maka dapat diketahui bahwa jika rata - rata penerimaan yang diperoleh petani sawi di Desa Petleng sebesar Rp. 3.740 .000 dan jika rata rata total biaya yang harus dikeluarkan petani sawi sebesar Rp. 788.200 maka diperoleh nilai R/C Ratio sebesar 4,74.

Artinya, setiap Rp 1 yang dikeluarkan oleh petani untuk biaya usahatani sawi maka akan menghasilkan keuntungan sebesar Rp 4,74. Karena nilai R/C Ratio lebih besar dari pada 1 ( $/ \mathrm{C}>1)$ maka usahatani sawi layak untuk diusahakan. 
Hasil penelitian ini sejalan dengan penelitian yang dilakukan oleh (Opat and Hutapea, 2017) Usahatani sawi manis yang dilakukan petani di Kelurahan Oelami menngunakan lahan sendiri memperoleh pendapatan rata-rata sebesar Rp. 1.791.835,354 dengan total pendapatan sebesar Rp. 59.130.566. Rata-rata keuntungan relatif dalam kegiatan usahatani sayur sawi manis yang diperoleh petani sebesar 2,86 artinya kegiatan usahatani sayur sawi manis yang dilakukan oleh petani di kelurahan Oelami menguntungkan dan Layak dikembangkan

\section{SIMPULAN}

1. Rata-rata Total Biaya Rp. 788.200, rata-rata Penerimaan Rp. 3.740.000 dan Rata-rata pendapatan usahatani adalah Rp. 2.951.800, hal ini berarti penerimaan petani dapat menutupi semua biaya yang dikeluarkan dalam proses produksi usahatani sawi di Desa Petleng.

2. $\mathrm{R} / \mathrm{C}$ usaha sawi di Desa Petleng lebih besar dari 1 yaitu 4,74, ini berarti bahwa usahatani sawi di Desa Petleng layak dikembangkan.

\section{DAFTAR PUSTAKA}

BPS Alor, 2019. Alor dalam angka 2020. BPS Kabupaten Alor.Dinas Pertanian Kabupaten Alor. 2020

Misri, 2013. Analisis Pendapatan Usahatani Sawi Di Desa Purwosari Kecamatan Kuala Pesisir Kabupaten Nagan Raya. Skripsi. Universitas Teuku Umar. Meulaboh. Aceh Barat.

Damanik, J.A., 2014. Analisis faktor-faktor yang mempengaruhi pendapatan petani padi di kecamatan masaran, Kabupaten Sragen. Economics Development Analysis Journal 3.

Nugroho, A., Rohmah, F., Al Rosyid, A.H., Suratiyah, K., 2015. Faktor yang Mempengaruhi Produksi dan Pendapatan Petani Kedelai di Kecamatan Paliyan Gunungkidul. Skripsi. Yogyakarta: Jurusan Sosial Ekonomi Pertanian Fakultas Pertanian Universitas Gajah Mada. 
Opat, E., Hutapea, A.N., 2017. Analisis Pendapatan Usahatani Sawi Manis di Kelurahan Oelami, Kecamatan Bikomi Selatan, Kabupaten Timor Tengah Utara. Agrimor 2, 33-35.

Rahim, A., Supardi, S., Hastuti, D.R.D., 2012. Model Analisis Ekonomika Pertanian.

Sinabariba, F.M., Prasmatiwi, F.E., Situmorang, S., 2014. Analisis efisiensi produksi dan pendapatan usahatani kacang tanah di Kecamatan Terbanggi Besar Kabupaten Lampung Tengah. Jurnal Ilmu Ilmu Agribisnis: Journal of Agribusiness Science 2, 316-322.

Sugiyono. 2011. Metode Penelitian Kuantitatif, Kualitatif dan R\&D. Bandung: Afabeta 